\title{
Destined to Fail? The History of the Yen Bloc before the Second World War
}

\author{
Woosik Moon
}

\begin{abstract}
The formation of yen bloc did not result in the economic and monetary integration of East Asian economies. Rather it led to the increasing disintegration of East Asian economies. Compared to Japan, Asian regions and countries had to suffer from higher inflation. In fact, the farther the countries were away from Japan, the more their central banks had to print the money and the higher their inflations were. Moreover, the income gap between Japan and other Asian countries widened. It means that the regionalization centered on Japanese yen was destined to fail, suggesting that the Co-prosperity Area was nothing but a strategy of regional dominance, not of regional cooperation. The impact was quite long lasting because it still haunts East Asian countries, contributing to the nourishment of their distrust vis-à-vis Japan, and throws a shadow on the recent monetary and financial cooperation movements in East Asia. This experience highlights the importance of responsible actions on the part of leading countries to boost regional solidarity and cohesion for the viability and sustainability of regional monetary system.
\end{abstract}

\section{Introduction}

There is now a growing literature that argues for closer monetary and financial cooperation in East Asia, reflecting rising economic and political interdependence between countries in the region. If such a cooperation happens, leading countries should assume corresponding responsibilities. For, the viability of the system depends on their responsible actions to boost regional solidarity and cohesion. Indeed, the historic experience of the past yen bloc shows that, given the absence of responsibilities of Japan, then the single most leading country, in maintaining the system, the so called "Asian Co-prosperity Sphere" created by the imperial Japanese government should fail.

This paper examines the process of the formation and dissolution of the yen bloc during the period of 1937 45 and intends thereby to highlight the importance of regional cohesion for the viability and sustainability of regional monetary system. In fact, the yen block started with the 
worldwide trend of regionalization during the 1930s depression. As a response to the regionalization, Japan intended to create its own bloc devoid of Western influence and on the basis of autarky. This idea gained the momentum with the start of the Sino-Japanese War in 1937. As the war was soon extended into the Pacific War and most of the East Asian countries were transformed into a set of colonies, satellites or occupied territories of Japan, Japan proposed the so called Greater East Asia Co-prosperity Sphere with the yen bloc as the basic principle regarding money and finance in East Asia. More precisely, the yen bloc can be defined similarly to the sterling bloc. Sterling area means two things. "In the first place, the sterling countries keep their exchange rats fixed in relation to the pound. Secondly they hold their external exchange reserves partly and wholly in sterling in the form of bank balances or short term investment in London"[League of Nations(1936)]. Interpreted in this way, East Asia during the World War II period was under the yen bloc, because the Japanese yen was the official anchor and at the same time other Asian countries than Japan had to hold yen balances. To this end, Japanese attempted "to divide the occupied regions into a number of appropriate districts in conformity with the administrative systems, and to let each district have its own system of note issuing central banks, the currencies issued by such institution being the only legal tenders of the respective districts and their value standards based on the Japanese yen"[The Oriental Economist(1942)].

The studies on the yen bloc were carried out mostly by Japanese authors[Kobayashi(1975), Shimazaki(1989)]. For instance, Shimazaki described the history of yen bloc as the history of invasion of Japanese yen. Iwatake focused on the competition and conflicts in China between different Japanese and Chinese currencies during the Second Sino-Japan War. Their main objectives were, however, to explain the history of the yen bloc from Japan's viewpoint and thus they did not pay enough attention to the monetary and financial difficulties experienced by other Asian countries. The question of regional cohesion and solidarity was either neglected or insufficiently addressed. Apart from these studies, there are also quite many studies describing the monetary and financial situation of many other Asian countries during the Japanese colonization period from their own perspective[Young(1965a), Banyai(1974), Bae(1990)]. For instance, Young traces out the historic development of Chinese monetary system minutely, collecting invaluable data and statistics on money, price and exchange rate in China. Banyai provides quite a comprehensive survey on money and banking in China and Southeast Asia during the period 1939 45. Bae focuses on monetary development of Korea during the colonial 
period. These studies could be used to understand the monetary developments and disarray in many Asian countries and regions caused by the Japanese attempts to extend the yen bloc.

This paper argues that the formation of yen bloc did not result in the economic and monetary integration of East Asian economies. Rather it led to the increasing disintegration of East Asian economies (refuting the endogeneity of the Optimum Currency Area). This is clear from the fact that the gap in inflation rate and income level between Japan and other East Asian countries widened during the Japanese occupation period. That experiment was frustrating for Asian countries. It means that the regionalization centered on Japanese yen was destined to fail, suggesting that the Co-prosperity was nothing but a simple propaganda of Japan. The impact was quite long lasting because it still haunts East Asian countries, contributing to the nourishment of their distrust vis-à-vis Japan, and throws a shadow on the recent monetary and trade cooperation movements in East Asia. This explains why ideas about regional monetary cooperation could rarely be heard of until the eruption of Asian currency crises.

The organization of this paper is as follows. In Section 2, the formation process of the yen bloc is described. In Section 3, the features of the yen bloc are examined together with its enlargement. In Section 4, the consequences of the yen bloc are investigated.

\section{The Formation of Yen Bloc}

Well before the formation of Yen bloc, silver dollar played a pivotal role in linking many countries in East Asia and the world. Since the $16^{\text {th }}$ century, Western silver coins including Spanish and Mexican dollars have been widely used in China, Japan and other East Asia. These imported silver dollars were standardized in form, weight and finesse, and thus convenient. They soon became the media of exchange, replacing Chinese tael(liang) as the unit of account in East Asian monetary system, and were given a name yuan (according to Chinese pronunciation), yen (according to Japanese one) and won (according to Korean one). ${ }^{(1)}$ Thus, there was already a natural currency zone in East Asia with silver dollar as unit of account. What Japan tried to accomplish with its idea of Yen bloc was nothing but to impose its own political and economic order to other East Asian counties on the basis of the military power. Naturally, the formation of

(1) Yuan, yen and won all means "round", because, unlike traditional Chinese and East Asian coins, Western coins were round without any rectangular hole in the center. 
the yen bloc goes along with the Japanese military occupation of Asian countries.

\subsection{First Step}

Japan was the first nation to modernize and successfully resist Western political and economic encroachments. Thus, Japan could have served as a model and aspiration to anti-colonial movements throughout Asia. Betraying this aspiration, however, Japanese leaders developed the same ambition as those of Western imperialist states and joined the global trend toward territorial expansion and colonialism. In the early $20^{\text {th }}$ century, Japan acquired its first colonial territories in Korea and Manchuria.

The idea for the yen bloc started with the colonization of these territories. The first Japanese bank that opened its business in Korea was the First Bank, established in 1873. Paralleling the deepening influence of Japan on Korea since the victory of Sino-Japanese war, the First Bank increased its business in Korea including the Korean government's finance and note issuing. In particular, to cope with chaotic monetary situation characterized by the circulation of numerous coins of different weights and standards, the First Bank was officially charged with harmonizing different currency standards and authorized to issue its own bank notes in Korea. To this end the Bank was allocated the maximum limit for the issuance of its notes, and at the same time, had to back up its issue by government securities and commercial papers as fiduciary reserves, let alone gold, silver and Japanese yen as specie reserves. After the Russo-Japanese war in 1905, Korea was declared a Japanese protectorate and then a colony, and at the same time the note issuing business of the First Bank came to be transferred to the newly created central bank, Bank of Chosun. ${ }^{(2)}$ It is to note it was mostly the Japanese yen that was served as its reserve assets in issuing the notes of the First Bank and later of the Bank of Chosun, which exchanged at par with Japanese yen. In this sense, Korea was considered as the first country in East Asia that adopted the yen standard system, which would constitute the core principle of Greater East Asia CoProsperity Sphere in monetary affaires[Shimazaki(1989)].

\subsection{Manchuria and China}

After the annexation of Korea, China would become a next candidate for Japanese expansionism because of its abundant resources and huge market potential. It did not start immediately, however. The Great Depression and the dislocation of world economy led to the

(2) Chosun is the old name for Korea. 
emergence of new nationalism and militarism in Japan, accentuating Japan's desire for regional integration and domination. Also, it pushed Japan for revoking the belated return to gold standard, which was decided on January 11, 1930. The re-suspension of the gold standard, however, does not mean the floating system, because Japanese government tried to maintain the exchange rate constant by the operation of the Exchange Stabilization (Equalization) Fund in the hand of government or by directly regulating demand itself for foreign exchange. Moreover, Foreign Exchange Control Act was put in force on May 1, 1933, concentrating all demands and supplies for foreign exchange into Government accounts. ${ }^{(3)}$

In 1931, Japan occupied Manchuria and soon established the new puppet government Manchukuo. Japan started the unification of currencies in Manchuria. There was a heterogeneous mixture of coins, weights, and paper money with their values fluctuating widely with each other. There were 15 different paper monies issued by provincial bank or currency bureaus. There was also a discussion on the currency standard. The reason was that the fluctuations in exchange rates due to the conflict between silver standard system and gold standard harm the regular business, causing lots of losses for the Japanese merchants, nourishing speculation. At the same time, the Central Bank of Manchuria was established at Shingking in 1935. The currency of Manchuria was linked to and exchangeable at par with the Japanese yen.

It is important to note that by integrating Manchuria to Chosun-Japan on monetary and economic affairs, Japan joined the world-wide trend of creating economic blocs, which developed later into the idea about Japan-Manchukuo-China Economic Bloc. Given that the world had already seen appearing a sterling bloc centered on the UK and its Commonwealth and a dollar bloc centered on the US, it implies that the world was entering into the era of closed and self-sufficient economic blocs, replacing the era of international cooperation represented by Washington conference system[Shimazaki(1989)].

The Marco Polo Incident took place on July 7, 1937, bringing Japan again into a war against China. The Second Sino-Japanese war snowballed of its own volition and finally the battle fronts extended over entire China, north from the Russian border to Central and south China. As Japan was in control of new areas, the management of newly occupied areas became urgent. So there followed the establishment of the Inner Monglia Bank (located at Kalgan), Chinese Federal

(3) Moreover, the exchange rate was pegged either against London 1 shilling 2 pence per 1 yen or against New York 23 dollars and 1/16 cents per 100 yen or to both. 
$<$ Table 1> Yen Bloc in the Occupied China

\begin{tabular}{|c|c|c|c|c|c|}
\hline & Issuing Bank & $\begin{array}{l}\text { Authorizing } \\
\text { Government }\end{array}$ & $\begin{array}{l}\text { Date of } \\
\text { creation }\end{array}$ & $\begin{array}{c}\text { Exchange } \\
\text { Rate }\end{array}$ & $\begin{array}{c}\text { Circulation } \\
\text { Area }\end{array}$ \\
\hline $\begin{array}{l}\text { National } \\
\text { Yuan }\end{array}$ & $\begin{array}{l}\text { Central Bank } \\
\text { of Manchuria }\end{array}$ & $\begin{array}{c}\text { Manchuria } \\
\text { Government }\end{array}$ & July 1, 1932 & Par with yen & Manchukuo \\
\hline Yuan Note & $\begin{array}{c}\text { Inner Mongolia } \\
\text { Bank }\end{array}$ & $\begin{array}{c}\text { Self-Gorverning } \\
\text { Mongolia Government }\end{array}$ & $\begin{array}{c}\text { November } 1, \\
1937\end{array}$ & Par with yen & Inner Mongolia \\
\hline Yuan Note & $\begin{array}{c}\text { Federal } \\
\text { Reserve Bank }\end{array}$ & $\begin{array}{l}\text { North China } \\
\text { Committee }\end{array}$ & $\begin{array}{c}\text { March 10, } \\
1938\end{array}$ & Par with yen & $\begin{array}{c}\text { North China, } \\
\text { Sandong, Sansu, }\end{array}$ \\
\hline Yuan Note & $\begin{array}{l}\text { Central Reserve } \\
\text { Bank } \\
\text { Hua Hsing Bank }\end{array}$ & $\begin{array}{c}\text { Government } \\
\text { at Nanking } \\
\text { New Government }\end{array}$ & $\begin{array}{c}\text { January 6, } \\
1941 \\
\text { May 6, } 1939\end{array}$ & $\begin{array}{c}18 \text { yen against } \\
100 \text { yuan }\end{array}$ & Central China \\
\hline $\begin{array}{l}\text { Military } \\
\text { Yen Note }\end{array}$ & & Japanese Army & $\begin{array}{c}\text { November, } \\
1937\end{array}$ & & \\
\hline
\end{tabular}

Source: Y. M. Bae(1990).

Reserve Bank (located at Peking) and Central Reserve Bank (located at Shanghai). Table 1 summarizes this movement.

Japan established the Inner Mongolia Bank at Kalgan on December 1 1937. This bank was authorized to issue banknotes, which were linked to the Japanese yen and Manchukuo Yuan at parity, and to handle the fiscal business of the puppet government and the public funds of the various local public bodies.

On March 10, 1938, the Federal Reserve Bank opened its business in Peking as the central banking institution for North China. The banknotes of the Federal Reserve Bank of China were linked to the Japanese yen and to Manchukuo Yuan at par, and, temporarily, linked to the National Yuan (or Fapi ${ }^{(4)}$ in Chinese $(\mathrm{CN} \$)$ ) of the Free China. De jure, its banknotes were backed by gold and silver and foreign currencies up to $40 \%$ or more of those issued. ${ }^{(5)}$

It is to note that at this time, Japanese yen was rapidly attaining the status of a key currency country similar to the US and its dollar in the Western Hemisphere. The Japanese yen was identified with the industrial and political strength of Japan[Banyai(1974)] and Japanese yen

(4) Fapi in Chinese means literally "legal tender."

(5) The capital of this bank was subscribed by puppet government provided by the loan made by Yokohama specie bank, Bank of Chosun and Industrial Bank of Japan. 
linked currencies such as the notes of Bank of Japan, Bank of Chosun and Central Bank of Manchukuo were widely circulating together with the Fapi, National Yuan (CN\$) notes issued by the National Government of Free China (KMT government). The Japanese military forces in North China initially used these currencies, especially the notes of Bank of Chosun, for their military expenditures. However, faced with the devaluation of these notes due to the overprinting, which made Japanese concerned with the devaluation of the Japanese yen linked to them, Japan decided to replace these notes by the notes of the newly created FRB of China, establishing its notes as the sole legal tender in North China.

Japan at the same time prohibited the circulation of the Fapi notes $(\mathrm{CN} \$)$ of the National Government of Free China. In North China, however, the Fapi banknotes remained firmly in circulation (especially in those occupied areas outside of Japanese control), and the notes of FRB did not dominate at all the circulation. The Fapi notes continued to circulate in competition with the notes of FRB. In fact, the Fapi was a secure and readily accepted currency for which people had confidence. The notes of the FRB of China were new and people were reluctant to accept it. Moreover, though the occupied area was immensely spacious, what Japanese army really put under control were cities and railways only, as signified by points and lines. It made it very complicated for the stationed Japanese armies to self-supply war materials. Even the Japanese were forced to obtain and use the Fapi notes to purchase the needed commodities from the country area. The National Government of Free China led the currency war against Japan at its advantage. The reason was that although it was linked to Japanese yen at par, the FRB note was inconvertible (no clause regarding the specie resumption). Thus its value had to be maintained by the exchange operations but its rate of exchange into foreign currency was fixed at too high a figure. To protect the value of the notes of the FRB of China, Japan had nothing but to rely on the comprehensive measures of trade and exchange control.

Similar developments ensued for Central China. As Central China fell under the Japanese occupation, Japan decided to establish Central Reserve Bank of Chin as a central banking institution for Central and South China. It opened its business on January 1941, taking over the business of the Hua Hsing Bank. Unlike in the case of North China, where Japanese military army used the note of Bank of Chosun, Japanese army in Central China used the yen notes of the Bank of Japan initially for its military outlays. As the amount of Japanese yen notes in circulation was becoming larger and larger, however, its value dropped and the Japanese yen 
was transacted at a discount with regard to other currencies. Many of these yen notes flowed back to Japan and upset the monetary management of Japan. Japan were concerned about continuing devaluation of the Japanese yen. To prevent the use of these yen notes back in Japan, Japan decided to withdraw the Bank of Japan yen notes from circulation in Central China and to substitute in their stead military scripts or military notes to finance its military spending. Although these military notes were denominated in yen and fixed at par with the Japanese yen, they were inconvertible to the yen and prevented from circulating in Japan and other areas. ${ }^{(6)}$ As a matter of fact, almost all Japanese yen linked currencies including the military notes were neither convertible into the note of the Bank of Japan nor into foreign currencies due to the exchange control. The value of the military notes vis-à-vis the Fapi, National Yuan of the National Government of Free China, varied widely from time to time and from place to place. The circulation remained limited, although it was enforced on many occasions by the military forces of Japan. Thus, similarly to the FRB of China, Japan decided to replace the military notes by the notes of the Central Reserve Bank of China. The value of the CRB notes was fixed at the rate of 18 yen against 100 yuan. Issuing the CRB yuan notes, Japan made it as the sole legal tender in Central China and banning all the circulation of the Fapi notes. The redemption of the Fapi with CRB yuan notes was made at the exchange rate of 2 to 1 (CN2 $\$=$ CRB1yuan). Also Japan undertook to withdraw the military notes on the condition that it would support the military outlays of Japan.

But to keep the exchange rate of the CRB notes stable turned out a heavy burden for the Japanese. In order to maintain it, the exchange control had to be reinforced gradually more strictly until at last all trade and foreign exchange transactions became impossible

\subsection{Currency War between China and Japan}

In the late 1920s as a result of imperialist rivalries and nationalist movements, the National Government of Free China (KMT) was able to bring nominal political unity to China after decades of war politics. In fact, the National Government could assume nationwide responsibility in 1928. It immediately recognized the urgency of economic and financial rehabilitation. Recognizing the need for a modern financial system, the new government created the Central Bank of China on October 6, 1928, which was to be reorganized as a true central

(6) These military notes were overprinted on yen note in large red characters denoting for military use only. 
bank. The bank was given the right to issue its own notes, to mint and circulate coins, to deal in foreign exchanges and to handle issuance and service of public loans. Notes were to have a reserve of $60 \%$ in silver or gold coin or bullion and $40 \%$ in government bonds or commercial paper.

Yet monetary situation remained chaotic until the currency reform in 1935. The currency consisted of money of endless variety, differing place to place. The first step in monetary reform was the coinage reform, abolishing the tael as unit of account and introducing standard silver dollar, named yuan. ${ }^{(7)}$ The second step took place in November 1935. The reform of 1935 nationalized silver and made notes of the Central Bank of China, Bank of China, and Bank of Communications full legal tender (Fapi) for all obligations in terms of silver. The exchange rate of the Fapi was fixed equal to 1 shilling 2 pences per 1 yuan. Also it created a Currency Reserve Board to control note issue and keep custody of note reserves. Use of silver as currency was forbidden, and prices were in Fapi, the sole legal tender, with a managed and stable foreign exchange standard[Young(1965b, p. 166)].

Because printing the banknotes was a major source of government finance for Japanese army as well as Nationalist Chinese Government, who faced up with continuing Japanese aggression, it turned out essential for wining the war between each other to win the currency war in which National Yuan (Fapi) and the currencies of Japanese sponsored banks competed with each other for stability and acceptability. As China managed to maintain independent management currency system, Fapi came to be supported by the UK and US, while the value of FRB and CRB notes by Japan.

To maintain the value of the Fapi, an Anglo-Chinese Exchange Stabilization Fund was set up on April 1939 with a capital of 10 million pound. Soon after its establishment, however, the Fund was faced with serious pressure. This is largely due to the flight of domestic capital and from Japanese purchases of foreign exchange with the Fapi obtained in the occupied areas of North China. Indeed, with the establishment of Federal Reserve Bank in North China, the Japanese withdrew the Fapi notes from circulation, replacing them with the notes of FRB, and used them at Shanghai foreign exchange market for the purchase of foreign exchange. It brought

(7) Until then, much of China's silver was in the form of silver 'shoes or sycee whose weight was expressed in taels (liang), and in bars. The tael was a unit of account. However, the tael's weight varied from place to place, sometimes within an area for different transactions. 
about a depreciation pressure on the Fapi. In the spring of 1940, the market condition became unfavorable once more and the Exchange Stabilization Fund had to withdraw from the market due to the establishment of Central Reserve Bank in Central China by the Japanese puppet government at Nanking. Thus to support the value of the Fapi, the National Government of Free China had to rely on foreign help again. This time, the help came from the US. On April 25, 1941, the Stabilization fund of the US Treasury agreed to grant $\$ 50$ million to the Chinese Stabilization fund for the purpose of stabilizing the value of Fapi in relation to the US dollar. At the same time, the British Treasury made a further contribution equivalent to L5 million to support the National Yuan in terms of sterling.

The maintenance of the free exchange market at Shanghai and the support of the Chinese currency by the Fund were to some extent inevitable for the stability of Fapi. Two reasons could be mentioned in this regard. In the first place, it was partly the very existence of a free market and of the possibility of conversion which it implied, that rendered the population of the occupied areas reluctant to give up their Chinese currency in exchange for the inconvertible currencies introduced by the Japanese puppet governments. It is reported that even in North China large amounts of Chinese notes remain in circulation or in hiding in spite of the severe penalties and prohibitions decreed by the Japanese authorities. Secondly, the existence of a reasonably stable exchange market tended to support the whole system of internal Government finance in free China. It helped to maintain a certain level of confidence in the currency and to check the flight into commodities on the part of the public.

Despite the currency war for stability, both the currencies of National Government of Free China and Japanese puppet Chinese governments circulated in parallel and China was plagued by hyper-inflation because the long lasting Sino-Japanese war necessitated ever increasing money printing for both governments. (See Table 4 below)

\section{Yen Bloc under the Greater East Asia Co-Prosperity Sphere}

\subsection{Establishment of the Great East Asia Financial Sphere}

The continual expansion by Japan into China led to deepening hostilities, especially between Japan and US. To check the military expansionism of Japan, the US prohibited its export of aluminum and scrap iron to Japan, froze Japanese assets in America and imposed a total 
embargo on oil exports to Japan. However it did not stop Japan from indulging in military expansionism into the South East Asia, paving the way toward the Pacific war, which finally broke out in 1941.

With its invasion into South East Asia, Japan set up more comprehensive policy regarding regional order under the slogan of Greater East Asia Co-Prosperity Sphere, which was to include not only Japan, China and Manchukuo but also the South Sea Area including French Indo-China, Thailand, Malay Peninsula, Philippines and Dutch East Indies. In fact, this Japanese idea was nothing but the prolongation of the New Order in East Asia announced by Foreign Minister Konoye on November 3, 1938, just after the outbreak of Sino-Japanese war. The concept of this New Order entailed the establishment of political and economic interdependence and mutual aid among the nations of Japan, Manchukuo and China. Japanese pointed out that such a union would take its place among the other blocs of Western powers, resisting their aggressive advances. Japan hoped that it would have ended Japan's dependence on the Western powers for its raw materials for Japanese industry too. Asia for Asians was another catchword. South Sea Area was essential to Japan as a source of raw materials such as coal, rice, iron, rubber and tin and in this respect fit in well with Japan's plan for Greater East Asia Co-Prosperity Sphere.

As Japan replaced the US and the European powers as the new imperialist state, the Pan-Asian idea was transformed into the propaganda under the name of the Greater East Asia Co-Prosperity Sphere. The German parallel was "Lebensraum."(8)

"We must show the races of East Asia that the order, tranquility, peace, happiness, and contentment of East Asia can be gained only by eradicating the evil precedent of the encroachment and extortion of the Anglo-Saxons in East Asia, by effecting the real aim of the co-prosperity of East Asia, and by making Japan the leader of East Asia."

Immediately after the outbreak of the Pacific War on December 1941, Japan established

(8) The lebensraum ("living space") was a popular political slogan during the establishment of a united Germany in 1871. At this time, Lebensraum usually meant finding additional "living space" by adding colonial territories. Hitler changed the concept of Lebensraum. Rather than adding colonies to make Germany larger, he wanted to enlarge Germany within Europe. Especially Hitler looked east for Germany's expansion in Europe. The Nazi modified theory of Lebensraum became Germany's foreign policy during the Third Reich. 
military administration in the occupied South East Asia (except for Indochina and Thailand), and to self-supply and cover up the increasing military and administrative expenditures, used military notes denominated in local currencies. These military notes were a general means of payment and circulated together with the pre-occupation local currencies. Indeed, Japanese military forces had already circulated a variety of military notes in yen issued exclusively for use in the occupied Central and South China. This predates the Japanese military notes issued for use in the South East Asia. However, the former is distinguished from the latter in the sense that it is denominated in Japanese yen, which is exchanged at par with Japanese yen. The exchange rate between the military notes denominated in local currencies of South East Asian countries and the Japanese yen was not fixed until 1943, after which it was decided to be at par. Also, to handle the military funds and to finance the long term development and construction of occupied, filling the gap left by the closing of existing local banks controlled by former colonial states such as the UK, Netherlands and the US, Japan created the Southern Development Cooperation in 1942. However, as the military expenditures continued to increase and the inflation in the occupied area is accelerating, this institution was allowed to issue its own notes and withdraw the military notes from March 1943 and thereby was to be transformed into de facto central bank of issue. The reason was that, to exploit the resources of the occupied area as much as possible, Japanese government had to eliminate the local currencies from circulation and to substitute in their place its own notes. (Similarly to South China)

In fact, during the Pacific war, the goal of the Japanese plan for financial control in the occupied areas was to establish its own Financial Sphere of Greater East Asia devoid of Western influence and thereby to exploit the occupied areas. The main principle of Japanese plan for the financial management of the Sphere was to use Japanese yen, for fixing the external value of the currencies of the Sphere, for maintaining a managed currency system, and for settling foreign exchange transactions in the Sphere, and thereby to eliminate old gold and silver standard or exchange system based on the US dollar and UK sterling. Briefly Japan hoped to set up a financial sphere with Tokyo as financial center, making yen as the anchor, reserve and settlement currency for Greater East Asia. The feature of this financial sphere can be examined in more detail as follows. 


\subsection{Features of Great East Asia Financial Sphere}

\subsubsection{Yen as a Anchor and the Par Link Policy}

To establish yen as the regional anchor currency, the currencies of the occupied areas became linked at par with the Japanese yen. First in the case of the Bank of Chosun and the Bank of Taiwan, it was stipulated in the law that their notes be convertible into Bank of Japan notes at par without any reservation. Among Japan proper, Korea and Taiwan, there was no restriction of any kind with regard to exchange, circulation and transactions. In the case of Central Bank of Manchuria notes, the conversion was allowed nothing but for the travelers. As mentioned, this step was taken to protect the value of yen from depreciating as the volume of money in circulation and inflation rate were rising more rapidly in Manchukuo. In the case of the Bank of Inner Mongolia and the Federal Reserve Bank notes, which were exchanged at par with the Japanese yen, and in the case of the Central Reserve Bank notes, which were converted to Japanese yen at a ratio of 18 Japanese yen to 100 Yuan, however, there was a strict exchange control.

Since the outbreak of Pacific War in 1941, Japan abolished foreign exchange floatation in terms of US dollars and UK pounds. The exchange markets vanished and the Japanese monetary authorities had to decide directly the conversion rate between yen and other currencies on the consideration of various elements such as productivity capacity, natural resources, standard of living, etc. The conversion rate between yen and the currencies of the South East Asian countries was set up to be at par, 1 to 1, except for French Indochina and Thailand, where the existing rates of exchanges were available. Moreover, the exchange transactions with US and UK were completely suspended and these were limited only to Germany and Italy as well as the countries in the Great East Asian Co-prosperity Sphere.

The par link of the currencies of South East Asian countries with Japanese yen implied that the value of these currencies dropped by two-folds, thereby reducing the import price of Japan by half compared with the level that prevailed in the prewar period and bring about the internal circulation of goods in Japan's favor. In fact, despite the fact that the conversion at par between yen and local currencies was unrealistic, this was possible due to trade and exchange control by the Japanese government. However, as the exchange rate became functionless as helping to correct trade imbalances or inflation rate differentials between different areas in the Sphere, there were lots of distortions and inefficiencies with the par link policy. Especially, as inflation 
differential with respect to Japan was accelerating in the occupied areas, Japanese government had to reinforce its trade and capital control. For, the imports of Japan from these areas tended to decline whereas the exports of Japan toward these areas increasing. (a hurdle for financing the necessary commodities for war).

Japanese government resorted to two policy measures. One was to use the subsidy system. It means that Japanese government charged the exporters as levy the differential between export price and domestic price and provided the differential between import price and domestic price as subsidy. The other was to use special conversion rate for Japanese imports. That is, importers were compensated for their loss in imports, using s special conversion rate between yen and the currencies of import areas.

\subsubsection{Yen as a Reserve Currency}

As mentioned, Japan established the central bank of issue or institutions of similar role in one occupied area after another, when necessity arose. These institutions in the occupied areas were subject to holding the reserves of the yen exchanges or the Bank of Japan notes. In fact, Bank of Japan extended on its own account monetary loans and credits to the various central banks of the Japanese controlled governments. ${ }^{(9)}$ The borrowing central banks had to hold the proceeds of loans as reserves on the books of the bank of Japan against their note issues.

Even though the holdings of the yen by the central banks of the East Asian countries was initially intended to raise the credit standings of the yen-linked currencies, Japan blocked the use of the yen balances held by East Asian countries so as to exploit the local economies for the increasing military spendings. The typical example was the introduction of the so-called Mutual Deposit System (Balances), forcing other East Asian countries to hold the blocked Japanese yen in return for their own local currencies. The Mutual Deposit System was first introduced between Chosun Bank and Yokohama Specie Bank on the one hand, and Federal Reserve Bank and Central Reserve Bank on the other hand, with the start of the Japanese occupation of China.

\subsubsection{Yen Based Settlement System}

During the pacific war, Japan introduced a clearing system, with the international transactions between nations being settled via transfers on the account of the central banks of the contracting

(9) They include Central bank of Manchukuo, Bank of Inner Mongolia, Federal Reserve Bank of China, Central Reserve Bank of China, Banque de l'indochine, Central Bank of Thailand, Central Bank of Burma and the proposed central bank of the Philippines. 
$<$ Table 2> Settlement System in East Asia

\begin{tabular}{|c|c|c|c|c|c|c|}
\hline From & Japan & Manchuria & Mongolia & North China & $\begin{array}{l}\text { Central and } \\
\text { South China }\end{array}$ & $\begin{array}{c}\text { South East } \\
\text { Asia }\end{array}$ \\
\hline Manchuria & $\begin{array}{c}\text { Yen (Direct exchange } \\
\text { with its own note and } \\
\text { Japanese yen) }\end{array}$ & & $\begin{array}{c}\text { Central Bank } \\
\text { of Inner } \\
\text { Mongolia } \\
\text { Note }\end{array}$ & $\begin{array}{c}\text { Federal } \\
\text { Reserve } \\
\text { Bank Note }\end{array}$ & $\begin{array}{c}\text { Special Yen } \\
\text { Account }\end{array}$ & $\begin{array}{c}\text { Special Yen } \\
\text { Account }\end{array}$ \\
\hline $\begin{array}{c}\text { Inner } \\
\text { Mongolia }\end{array}$ & $\begin{array}{l}\text { Federal Reserve Bank } \\
\text { Note (Indirect via the } \\
\text { exchange of its own note } \\
\text { and the note of Federal } \\
\text { Reserve Bank and then } \\
\text { by the exchange of the } \\
\text { latter with Japanese yen) }\end{array}$ & $\begin{array}{l}\text { Central Bank } \\
\text { of } \\
\text { Manchukuo } \\
\text { Note }\end{array}$ & & $\begin{array}{c}\text { Federal } \\
\text { Reserve } \\
\text { Bank Note }\end{array}$ & $\begin{array}{c}\text { Special Yen } \\
\text { Account }\end{array}$ & $\begin{array}{c}\text { Special Yen } \\
\text { Account }\end{array}$ \\
\hline $\begin{array}{l}\text { North } \\
\text { China }\end{array}$ & $\begin{array}{c}\text { Yen } \\
\text { (direct exchange) }\end{array}$ & $\begin{array}{c}\text { Central Bank } \\
\text { of } \\
\text { Manchukuo } \\
\text { Note }\end{array}$ & & & $\begin{array}{c}\text { Note of } \\
\text { Central } \\
\text { Reserve Bank } \\
\text { Special Yen } \\
\text { Account }\end{array}$ & $\begin{array}{c}\text { Special Yen } \\
\text { Account }\end{array}$ \\
\hline $\begin{array}{l}\text { Central and } \\
\text { South } \\
\text { China }\end{array}$ & $\begin{array}{c}\text { Yen } \\
\text { (direct exchange) }\end{array}$ & $\begin{array}{c}\text { Special Yen } \\
\text { Account }\end{array}$ & $\begin{array}{c}\text { Special Yen } \\
\text { Account }\end{array}$ & $\begin{array}{c}\text { Federal } \\
\text { Reserve } \\
\text { Bank Note } \\
\text { Special Yen } \\
\text { Account }\end{array}$ & & $\begin{array}{c}\text { Special Yen } \\
\text { Account }\end{array}$ \\
\hline $\begin{array}{l}\text { South East } \\
\text { Asia }\end{array}$ & $\begin{array}{l}\text { Special Yen Account } \\
\text { Yen (Direct exchange of } \\
\text { the note of Southern } \\
\text { Development } \\
\text { Corporation with yen) }\end{array}$ & $\begin{array}{c}\text { Special Yen } \\
\text { Account }\end{array}$ & $\begin{array}{c}\text { Special Yen } \\
\text { Account }\end{array}$ & $\begin{array}{c}\text { Special Yen } \\
\text { Account }\end{array}$ & $\begin{array}{c}\text { Special Yen } \\
\text { Account }\end{array}$ & \\
\hline
\end{tabular}

Source: Shimazaki(1989).

countries. In fact, this clearing system was modeled after the German Nazi's system, in contrast to the then UK or US system that consisted of setting up an exchange stabilization fund and intervening in the exchange market to fix the exchange rate[Shimazaki(1989)]. Japan concluded many bilateral clearing contracts with the governments of the occupied and satellite areas. The first of these clearing agreements was made between Yokohama Specie Bank and Java Bank in December 1940. Since then, Yokohama Specie bank concluded 7 more contracts, with the Bank 
of Chosun and Bank of Japan doing 1 contract respectively. In 1942, Japanese government decided to make Bank of Japan as the leading central bank and clearing institution in the area and the Bank of Japan Act was revised so as to implement the settlements between nations via transfers in the special yen account that central banks of the occupied areas maintain in the form of deposit at the Bank of Japan. Despite this attempt, however, the Bank of Japan could not succeed in replacing the Yokohama Specie Bank, a special foreign exchange bank handling the Japanese government account overseas, as the central clearing institution in the yen bloc area and the settlement system remained fragmentary.

\section{Consequences of the Yen Bloc: Increasing Divergence}

Contrary to the propaganda of Greater East Asia Co-Prosperity Sphere, there were widening economic disparities between Japan, its colonies and occupied areas. This increasing economic divergence can be examined in two respects. One is the inflation gap and the other is the income gap, which can be measured relying on the data collected by Maddison(1995).

\subsection{Inflation Gap}

During the Japanese occupation, East Asia was also plagued by high inflation, with each area having its own system of note issuing bank and currency. It is noteworthy that compared to Japan and its close colonies, the regions at long distance such as Central and South China and South East Asian countries recorded relatively higher inflation. For instance, the inflation rate at the eve of the defeat of Japan in 1945 in Tokyo was little more than two times as high that in 1937, but reached several thousand or ten thousand times in China and South East Asia.

In fact, Table 3 shows that the farther away the region in question was from Tokyo, the higher seemed its inflation rate. Thus, there was also a widening inflation differential between Japan and other East Asian countries.

This was because the use of the yen linked currencies was not voluntary but imposed on the occupied regions. The occupied regions were especially obliged to meet the increasing Japanese war expenses, and as a consequence, their local central banks, most of which would be controlled by Japan, had to issue more and more the money. In fact, the farther the regions were away from Japan, the higher was the increase in their money supply, paralleling the inflation rate movement. This is clear from Table 4. 
<Table 3> Movements of Wholesale Price Index in East Asia

\begin{tabular}{|c|c|c|c|c|c|c|c|c|c|c|c|}
\hline & \multirow[b]{2}{*}{ Japan } & \multirow[b]{2}{*}{ Taiwan } & \multirow[b]{2}{*}{ Korea } & \multicolumn{4}{|c|}{ China } & \multirow[b]{2}{*}{ Philippines } & \multirow[b]{2}{*}{ Java } & \multirow[b]{2}{*}{ Singapore } & \multirow[b]{2}{*}{ Myanmar } \\
\hline & & & & $\begin{array}{c}\text { Manch- } \\
\text { uria }\end{array}$ & $\begin{array}{l}\text { North } \\
\text { China }\end{array}$ & $\begin{array}{l}\text { Central } \\
\text { China }\end{array}$ & $\begin{array}{c}\text { Free } \\
\text { China }\end{array}$ & & & & \\
\hline & Tokyo & Taipei & Seoul & Shinking & Beijing & Shanghai & Chungking & Manila & Batavia & & Langoon \\
\hline 1937.12 & 100 & 100 & 100 & 100 & $100 * *$ & 100 & 100 & & & & \\
\hline 1938.6 & 105 & & 118 & 130 & & 88 & 113 & & & & \\
\hline 1938.12 & 106 & 113 & 115 & 125 & & 93 & 139 & & & & \\
\hline 1939.6 & 112 & & 106 & 146 & & 123 & 171 & & & & \\
\hline 1939.12 & 130 & 126 & 115 & 159 & 262 & 248 & 275 & & & & \\
\hline 1940.6 & 127 & & 119 & 186 & 430 & 370 & 488 & & & & \\
\hline 1940.12 & 129 & 141 & 120 & 192 & 410 & 527 & 983 & & & & \\
\hline 1941.6 & 139 & & 123 & 197 & 439 & 719 & 1365 & & & & \\
\hline 1941.12 & 146 & 147 & 125 & 208 & 518 & 1290 & 2322 & 100 & 100 & 100 & 100 \\
\hline 1942.6 & 150 & 151 & 128 & 212 & 646 & 2161 & 4183 & & 140 & & \\
\hline 1942.12 & 151 & 151 & 132 & 235 & 817 & 3976 & 6965 & 200 & 134 & 352 & \\
\hline 1943.6 & 161 & 160 & 142 & 241 & 1184 & 5944 & 11044 & 247 & 166 & 807 & 900 \\
\hline 1943.12 & 168 & 169 & 147 & 255 & 1382 & 14194 & 19826 & 1196 & 227 & 1201 & 1718 \\
\hline 1944.6 & 181 & 179 & 159 & 282 & 2156 & 46452 & 40696 & 5154 & 492 & 4469 & 3635 \\
\hline 1944.12 & 193 & & 166 & 338 & 5901 & 202419 & 56348 & 14285 & & 10766 & 8707 \\
\hline 1945.6 & 250 & & 181 & $454^{*}$ & $15348 *$ & 2404919 & 177565 & & 2421 & & 30629 \\
\hline 1945.8 & 264 & & & & & 6967742 & 213913 & & 3197 & & 185648 \\
\hline
\end{tabular}

Note: *: May, 1945.

$$
\text { **: As of the } 1936 \text {. }
$$

Source: Shimazaki(1989), Young(1965a), Monthly Statistics of Chosun Bank, each issue.

One important instrument that obliged the occupied East Asian countries to issue more and more money was "the Local Borrowing System" introduced in 1943. Basically, the introduction of this system was due to the fact that with the rapid rise of inflation in the occupied area, occurred as a result of the increase in military spending, Japan had to procure ever more increasing amount of the Japan-sponsored currencies to cover up its military spendings. Given that the exchange rate of Japan sponsored currencies were fixed at par with Japanese yen, however, it means that the issue of the Japanese yen would have to increase as well. To prevent this situation, Japan decided to rely on the borrowings of local currencies, making use of the Mutual Deposit System (as mentioned in the case of FRB and CRB notes), direct borrowing agreement (the case of Central Bank of Manchuria notes) and the operation of Special Yen 
< Table 4> Note Issues by Different Japan Rated Banks and Central Bank of China (Million Yen or Yuan)

\begin{tabular}{|c|c|c|c|c|c|c|c|c|c|c|c|c|c|}
\hline & \multirow{2}{*}{$\begin{array}{c}\text { Japan } \\
\text { BOJ } \\
\text { Yen }\end{array}$} & \multirow{2}{*}{\begin{tabular}{|c|} 
Taiwan \\
BOT \\
Yen
\end{tabular}} & \multirow{2}{*}{$\begin{array}{c}\text { Korea } \\
\text { BOC } \\
\text { Yen }\end{array}$} & \multicolumn{5}{|c|}{ China } & \multicolumn{5}{|c|}{ Southern Development Corporation(a) } \\
\hline & & & & Manchu & Mongol & Federal & Central & $\begin{array}{c}\text { Free } \\
\text { China }\end{array}$ & $\begin{array}{c}\text { Phil } \\
\text { (Peso) }\end{array}$ & $\begin{array}{l}\text { Burma } \\
\text { (Rupee) }\end{array}$ & $\begin{array}{c}\text { Malai } \\
\text { Dollar(b) }\end{array}$ & $\begin{array}{c}\text { Gulden } \\
\text { (c) }\end{array}$ & Total \\
\hline 1937 & 2305 & 112 & 279 & 307 & 13 & & & 1639 & & & & & \\
\hline 1938.6 & 2074 & 105 & 254 & 275 & 18 & 59 & & 1727 & & & & & \\
\hline 1938.12 & 2754 & 140 & 321 & 426 & 36 & 162 & & 2305 & & & & & \\
\hline 1939.6 & 2522 & 146 & 285 & 388 & 32 & 264 & & 2700 & & & & & \\
\hline 1939.12 & 3679 & 171 & 443 & 624 & 60 & 458 & & 4287 & & & & & \\
\hline 1940.6 & 3597 & 176 & 437 & 632 & 57 & 599 & & 6063 & & & & & \\
\hline 1940.12 & 4777 & 199 & 462 & 947 & 93 & 715 & & 7867 & & & & & \\
\hline 1941.6 & 4247 & 197 & 509 & 811 & 66 & 691 & 60 & 11296 & & & & & \\
\hline 1941.12 & 5978 & 252 & 741 & 1262 & 114 & 964 & 237 & 15133 & & & & & \\
\hline 1942.6 & 5545 & 250 & 667 & 1106 & 83 & 937 & 1172 & 22975 & & 34 & & & 34 \\
\hline 1942.12 & 7418 & 289 & 908 & 1670 & 143 & 1581 & 3477 & 34360 & 106 & 137 & 149 & 83 & 463 \\
\hline 1943.6 & 7363 & 321 & 864 & 1800 & 176 & 1949 & 9122 & 49873 & 229 & 327 & 244 & 145 & 945 \\
\hline 1943.12 & 10266 & 415 & 1466 & 3011 & 379 & 3762 & 19150 & 75379 & 497 & 664 & 425 & 369 & 1955 \\
\hline 1944.6 & 12323 & 519 & 1817 & 3512 & 416 & 5995 & 38359 & 122779 & 1115 & 1544 & 752 & 803 & 4246 \\
\hline 1944.12 & 17745 & 796 & 3135 & 5877 & 1058 & 15841 & 139699 & 189461 & 4948 & 2774 & 1438 & 1464 & 10623 \\
\hline 1945.6 & 26181 & 1207 & 4376 & & $2799 a$ & 55390 & 738273 & 397773 & & & 3147 & & \\
\hline 1945.8 & 42300 & 2285 & 7987 & 8800 & 3600 & 132603 & 2697231 & 556907 & & 5656 & 5640 & 2792 & 19468 \\
\hline
\end{tabular}

Source : Bank of Japan (1970), Young (1965a).

(a) Issued in local currency units but linked at par with Japanese yen.

(b) Issued for Malaysia, Singapore and Borneo.

(c) Issued for Java and Sumatra area.

Account (the case of Thai Baht and Indo-China Bank notes). In fact, this system helped Japanese government to create as much local currencies as it wished. For instance, the use of the Mutual Deposit accounted for more than $70 \%$ of the total money issued by the Central Reserve Bank and was an important cause of inflation.

Under this condition, the supply of the bank notes in the Occupied China was dependent on the Japanese government's order to balance with the increasing demand for money caused by Japanese imperialist war. This system led to bring more inflation in the occupied China than Japan and its close colonies such as Korea and Taiwan. ${ }^{(10)}$ In turn, it touched off the hyper-

(10) In Free China, National government of China was also obliged to issue its own money to finance the war against Japan. For the detailed explanation, see Young(1965a). 
inflationary spiral in the Fee China area, which was the most serious in Chinese history, because the Nationalist Chinese Government (KMD regime) was also forced to finance the increasing war expenses by issuing its currency. ${ }^{(11)}$

Moreover, for South-East Asian countries (except for Thailand and Indo-China), Japanese military authorities themselves issued their own notes (military notes) in local units, although they soon had to be replaced by the notes of Southern Development Corporation. Unlike central banking institutions in other occupied areas, however, the Southern Development Corporation had no maximum limit and no backing requirement for the note issue. Consequently, this region had to suffer higher inflation.

\subsection{Growth Gap}

Not only in the monetary matters but also in terms of real income, the gap between Japan and its neighboring countries widened. A. Maddison (1995) offers quite a comprehensive data for the prewar period national income in some selected East Asian countries. Although incomplete and sometimes very roughly estimated, it is the only available one that makes in common unit the comparison of national income between countries during the period of Japanese expansion. It will be thus useful enough to look at the changes of per-capital incomes of the East Asian countries on the basis of his study.

Table 5 shows the trend of per capital GDP in different parts of East Asia relative to that of Japan during the period 1910 1950. It suggests that the economic gap between Japan and its colonies and occupied areas (measured in per capita GDP) has continued to be widened. For instance, during the period 1913 1929, the per-capita incomes of Taiwan and Korea, Japan's colonies since 1895 and 1910 respectively, fell from 59\% and 71\% of Japanese per capita income to $56 \%$ and 59\%. This trend was temporarily suspended during the period 1929 to 1938 . During the war period 1938 to 1945, however, the decline in per capita incomes of Korea and Taiwan relative to Japan resumed. This trend continued even after the end of the World War II. As a result, for the period from 1913 to 1950, the relative per capita incomes of Korea and Taiwan dropped from $59 \%$ and $71 \%$ of Japanese income to $46.8 \%$ and $49.2 \%$. Even though the

(11) The currency war with Japan intensified the internal contradictions of the Nationalist Chinese Government regime, providing a good political space for the Communist to operate. Indeed, it led to Communist revolution in 1949. In this sense, not only Japan but also China were losers of the currency war. 
<Table 5> Per Capita GDP Relative to Japanese Income (\%)

\begin{tabular}{|c|c|c|c|c|c|c|c|c|}
\hline Year & Japan & China & Korea & Taiwan & Indonesia & Philippines & Thailand & Burma \\
\hline 1910 & 100 & & & 76.40 & 67.30 & & & \\
\hline 1911 & 100 & & 68.87 & 67.64 & 67.71 & & & 43.10 \\
\hline 1912 & 100 & & 67.87 & 59.08 & 66.07 & & & \\
\hline 1913 & 100 & 51.57 & 71.06 & 59.52 & 68.74 & 106.30 & 63.42 & 47.60 \\
\hline 1914 & 100 & & 78.06 & 62.54 & 71.24 & & & \\
\hline 1915 & 100 & & 81.16 & 58.47 & 66.33 & & & \\
\hline 1916 & 100 & & 71.43 & 60.14 & 58.67 & & & 48.60 \\
\hline 1917 & 100 & & 73.66 & 63.42 & 57.43 & & & \\
\hline 1918 & 100 & & 78.26 & 59.07 & 58.32 & & & \\
\hline 1919 & 100 & & 69.00 & 56.77 & 56.94 & & & \\
\hline 1920 & 100 & & 71.55 & 56.47 & 59.66 & & & \\
\hline 1921 & 100 & & 68.14 & 50.42 & 54.44 & & & 36.78 \\
\hline 1922 & 100 & & 66.74 & 53.92 & 55.85 & & & \\
\hline 1923 & 100 & & 68.41 & 55.26 & 56.81 & & & \\
\hline 1924 & 100 & & 67.06 & 58.52 & 58.46 & & & \\
\hline 1925 & 100 & & 64.77 & 57.39 & 58.16 & & & \\
\hline 1926 & 100 & & 66.57 & 56.80 & 60.97 & & & 41.87 \\
\hline 1927 & 100 & & 69.54 & 55.31 & 64.42 & & & \\
\hline 1928 & 100 & & 62.86 & 56.44 & 62.49 & & & \\
\hline 1929 & 100 & 39.97 & 59.72 & 56.80 & 61.93 & 80.25 & 41.00 & \\
\hline 1930 & 100 & 44.16 & 65.90 & 62.47 & 67.30 & & & 46.97 \\
\hline 1931 & 100 & 44.57 & 64.31 & 60.63 & 63.12 & & & \\
\hline 1932 & 100 & 42.77 & 61.74 & 64.28 & 57.02 & & & \\
\hline 1933 & 100 & 39.23 & 64.20 & 54.31 & 51.37 & & & \\
\hline 1934 & 100 & 36.01 & 63.15 & 57.50 & 50.72 & & & \\
\hline 1935 & 100 & 38.33 & 69.61 & 63.24 & 50.69 & & & \\
\hline 1936 & 100 & 38.30 & 69.38 & 59.89 & 49.84 & & & 35.99 \\
\hline 1937 & 100 & 36.06 & 75.48 & 57.97 & 51.86 & & & \\
\hline 1938 & 100 & 33.02 & 69.99 & 56.03 & 48.22 & 63.54 & 35.31 & 29.07 \\
\hline 1939 & 100 & & 53.89 & 52.01 & 41.49 & & & \\
\hline 1940 & 100 & & 58.52 & 49.37 & 42.93 & & & \\
\hline 1941 & 100 & & 59.66 & 52.75 & 44.36 & & & \\
\hline 1942 & 100 & & 59.02 & 56.14 & 35.15 & & & \\
\hline 1943 & 100 & & 59.21 & 37.25 & 29.59 & & & \\
\hline 1944 & 100 & & 58.01 & 27.09 & 23.81 & & & \\
\hline 1945 & 100 & & 53.05 & 57.76 & 39.69 & & & \\
\hline 1946 & 100 & & 49.96 & 58.24 & 37.94 & & & \\
\hline 1947 & 100 & & 49.06 & 60.93 & 41.09 & & & \\
\hline 1948 & 100 & & 46.81 & 55.78 & 44.10 & & & \\
\hline 1949 & 100 & & 47.83 & 53.26 & 46.79 & & & \\
\hline 1950 & 100 & 32.78 & 46.77 & 49.23 & 46.66 & 69.03 & 45.27 & 20.98 \\
\hline
\end{tabular}

Source : Maddison(1995). 
precise data for the income level during the war period is missing, the widening income gap relative to Japan is quite the same for other occupied areas such as China and Southeast Asia. For instance, China was not the colony but its sovereignty was limited by Japan (and Western powers) until the defeat of Japan in 1945. Its per-capita income declined from $51 \%$ of the Japanese in 1913 to $33 \%$ in 1938 and 32\% in 1950. The same trend is true for Southeast Asian countries. Given that until late 1930s Southeast Asian countries were not yet under Japanese control, it was likely that the rising economic gap between Japan and these latter countries might reflect the former colonial economic structure rather than the result of the Japanese occupation. It is however still true that Japanese occupation of these countries did not bring about the coprosperity promised by Japan. In fact, as some observers put it, "the Japanese occupation caused economic havoc in the so called liberated territories. The entire economic life of the region regressed to the level of subsistence production and barter trade. The economic gulp has widened between developed Japan and underdeveloped South East Asia.”

It means that even on pure economic ground the yen bloc doomed to failure, because the unity of the bloc cannot be maintained in the face of widening diversities. In fact, after the military defeat of Japan in World War II, most of the newly independent East Asian countries broke its link to Japanese yen and adopted dollar standard system, while former British colonies such as Hong Kong, Singapore and Malaysia returned to the link of British Sterling until the breakdown of the Sterling Area in the early 1970s. No single country in the region did want to remain in the yen bloc.

The exact reason why these countries were relatively more backward than Japan is very difficult to know because the experience of these periods were very complex, compounded by war and worldwide depression etc. But the growth performance during and after this period suggest a hint about what might have happened in Asia if these countries had regained their sovereignty. In fact, Japan achieved far faster growth than any other Asian countries, for instance by earlier nation-building and westernizing its institutions. Other countries were late in these efforts or at least prevented from doing so by Japan. After the defeat of Japan, however, other East Asian countries could take off, starting the process of catch up with Japan. The catch up was evident especially since the1970s. ${ }^{(12)}$

(12) For instance, the per capita incomes of Korea and Taiwan in 1970 were respectively $23.3 \%$ and $24.4 \%$ of the Japanese income but since then they rose to $48.3 \%$ and $55.6 \%$ in 1990 and in 2000 . 


\section{Conclusion}

Japanese idea about the monetary management of the Greater East Asian Co-prosperity Sphere dates back to the integration of Korea and Manchuria to Japan. It is extended through the Japan-Manchukuo-China Economic Bloc to the idea of Great East Asian Co-prosperity Sphere. No matter how the idea developed, however, there was the same underlying objective: to exploit the neighboring economies as much as possible to the sole benefit of Japan. In fact, the experience of the Japanese invasion and occupation period shows that the economic and inflationary gap between Japan and other East Asian countries continued to be widened. There was no effort to fill the gap, showing the solidarity necessary for the maintenance of the bloc. Rather, the other East Asian countries had to sacrifice their interests to support Japanese military expansionism unilaterally. Indeed, it looks like that what Japan attempted to achieve was to establish the hierarchical relation between the countries that dominate and are dominated. It means that Japan pursued a strategy of regional dominance, not of regional cooperation. Clearly it could not be acceptable to East Asian countries otherwise than on the basis of military forces. Moreover, all these ideas were based on nationalism, which included exclusiveness and closedness to the other parts of the world. It means that the so called Co-prosperity was nothing but a Japanese propaganda.

The result was that after the Word War II, it took relatively very long time for Japan to normalize its diplomatic relation with neighboring Asian countries. Even after the economic relation with Japan became quite important, it helped these countries to distrust Japan, justifying the reluctant attitude of East Asian governments toward Japan initiated ideas regarding regional monetary and trade cooperation. In fact, the US emerged as the new and sole hegemonic power in the region. Under American leadership, the postwar East Asian economy became much more liberal, multilateral, and interdependent. This new world order led to an unprecedented expansion of the East Asian and world economy, providing a good opportunity to fill the economic gap that existed between East Asian countries and the US on the one hand and the Japan on the other hand. This is another good reason why Japan initiative ideas about regional cooperation received only a very lukewarm welcome in the region.

Similar trend is observed for other East Asian countries. 
Professor, Graduate School of International Studies, Seoul National University

599 Gwanak-ro, Gwanak-gu, Seoul, 151-742, Korea.

Phone: 82-2-880-8524

Fax: 82-2-889-8524

E-mail:mwoosik@snu.ac.kr

\section{References}

Bae, Yeung Mok(1990): "A Study on Money and Banking during the Colonial Period in Korea," Seoul National University (in Korean).

Banyai, R.(1974): Money and Banking in China and Southeast Asia During the Japanese Military Occupation, 1937 1945, Taipei, Tai Wan Enterprise Co..

Bank of Japan(1970): “Nihonkinyushisiryo,” Showa Period, 27 (in Japanese).

Hao, Yen-P'ing(1986): The Commercial Revolution in Ninteenth-Century China, Univ. of California Press.

Kim, J. H.(1998): “A Study on the Currency War During the Sino-Japanese War,” (in Korean).

Kobayashi, H.(1975): The Formation of East Asian Co-prosperity Zone and its Collapse, Tokyo (in Japanese).

League of Nations(1936): Series of League of Nations Publications, II. Economic and Financial.

Maddison, Angus(1995): Monitoring the World Economy 1982 1992, Development Center, OECD.

Ministry of Treasury, Japan(1970): History of Showa Public Finance (in Japanese).

Shimazaki, H.(1989): The History on the Invasion of the Yen, Tokyo, Nihonkeizaihyoronsha (in Japanese).

Oriental Economist(1942): “Money and Banking," September. (1941): “Yen Linked Currencies Firm,” July.

Young, A. N.(1965a): China's Wartime Finance and Inflation, 1937 1945, Harvard University Press. Young, A. N.(1965b): China's Nation Building Effort, 1927 1937, Harvard University Press. 
